Katarina Bedina Ljubljana

\section{FENOMEN GLASBENEGA BAROKA NA SLOVENSKEM}

Kultura je sad neskončnega trajanja. Tisto, česar družba ne more, se kulturi posreči.

F. Braudel, Čas sveta

Ob tej priložnosti, ko bo tekla v rojstnem kraju beseda o Giuseppu Tartiniju, geniju italijanskega izročila, se samo po sebi odpira vprašanje slovenskega glasbenega zaledja njegove življenjske dobe (1692-1770). Ta čas zaobjema baročno obdobje v slovenski glasbi, od zgodnjih začetkov do sklepne faze z Akademijo filharmonikov in sega do razkroja baročne miselnosti sredi 18 . stoletja $0 z$. v pripravo močno zadržanega klasicizma na naših tleh. $\mathrm{Na}$ tem mestu ne bomo govorili o splošno znanih posameznostih in dogodkovni površini, ker je bila (tudi v tujih jezikih ${ }^{1}$ ) že večkrat predstavljena. Pritegnila nas je druga iztočnica, današnja aktualnost baroka. $V$ zadnjih dvajsetih letih opažamo $v$ muzikologiji in drugih umetnostnih vedah nenavadno živo zanimanje za duhovne in socialne razsežnosti baroka. Za univerzum kulture in sloga, ki s pojmom univerzalnega nima veliko skupnega. Obenem za nalesljiv način izražanja in vedènja, ki je obvladoval evropski prostor $v$ mnogoterih različicah s skupnim imenovalcem. Današnjo aktualnost baroka je razumeti na več načinov. Raziskovalce umetnosti privlači predvsem obujena misel Augusta Halma o dveh kulturah, ki že od nekdaj uravnavata svet, klasični in baročni. Naš osnovni interes bo veljal vprašanju, zakaj smemo dandanes glasbo baročnega obdobja na Slovenskem označiti s fenomenom.

Barok $v$ slovenski glasbi se je začel $z$ nasilno in popolno odpravo protestantskega gibanja pod valom obnovljene katoliške cerkvene moči. Začetek je padel v tisti trenutek, ko so protestanti želi prve, težko priborjene uspehe. S književnimi prvenci, prvim prevodom Biblije in slovensko slovnico so poskrbeli za ozaveščanje slehernega posameznika, obenem za samobitni kulturni kapital, ki je ostal vse do danes razumljen kot izvor popolne kulturne osamosvojitve Slovencev. Z njim so protestanti prišli do kratkotrajne politične nadmoči. Uspelo jim je povezati niti dotlej razpršenega slovenskega prostora $\vee$ občutje etnične skupnosti. Nadaljnjo perspektivo protestantskega gibanja je naglo in brezobzirno pretrgal spopad $z$ idejo rekatolizacije slovenskega prebivalstva. Preobrat se je dogajal v težkih,

1 V izboru navajam le bibliografijo v tujih jezikih: D. Cvetko, Histoire de la musique slovène, Maribor 1967; isti, Musikgeschichte der Südslawen, Kassel-Maribor 1975; isti, II barocco musicale in Slovenia, v: Barocco in Italia e nei paesi del sud, Firenze 1983, 261-273; J. Höfler, Die Strömungen der Musikkultur in Slowenien von Anfängen bis zum 19. Jahrhundert, v: Tokovi glasbene kulture na Slovenskem od začetkov do 19. stoletja, Ljubljana 1970 - Zusammenfaßung, 193-199. 
pogosto travmatičnih okoliščinah. Turški vpadi in množični (organizirani, a neuspeli) kmečki upori so opustošili življenje na vseh ravneh. Protestantska ideja je zagovarjala skromnost in vero, ki naj bo stvar osebnega notranjega poglabljanja brez blišča in vnanjih afektov. Glasba protestantskih ideologov ni zanimala toliko kot pisana beseda $v$ domačem jeziku, zavedali pa so se, da lepota pétih pobožnosti privablja nove vernike. Natisnili so enoglasne pesmarice na slovensko besedilo, oživeli ljudsko petje $v$ cerkvah, toda na sočasen razcvet renesančne glasbe $v$ tujih deželah se niso odzvali. To se zdi, spričo opustošene dežele, razumljivo. $Z$ današnjega zornega kota ni težko presoditi, da so izgubili stik $z$ umetnostnim vrenjem časa, ki so ga živeli, in s tem bistveno vplivali na konec lastne usode in seveda na zgodovinski spomin $v$ slovenski glasbi. $Z$ renesančnim idiomom $v$ glasbi je deloma in zasebno korespondirala le tanka plast na italijanskih univerzah vzgojenega plemstva.

Obratno razmerje do glasbe je bilo značilno za ideologijo katoliške cerkvene obnove. Preizkušen utilitaristični namen $z$ glasbo je na naših tleh presegla prav na začetku, $v$ devetdesetil letih 16 . stoletja, $z$ vsemi registri psihološko-čustvenega vpliva in moči, ki jo zmore tonska umetnost. Novo politiko je $v$ začetku vodil ljubljanski škof Tomaž Hren na dobro pripravljenih idejnih izhodiščih svojega predhodnika, Janeza Tavčarja. ${ }^{2}$ Terjal je celovito spremembo $v$ načinu mišljenja in bivanja. Najprej in najmočneje se je pokazala $v$ glasbi, pozneje in postopno še $v$ drugih dveh simbolih baročne umetnosti, zlatih oltarjih ter iluzionističnem slikarstvu. Prejšnji individualizem in skromnost sta $v$ hipu, nekakšnem mrzlično-vročičnem stanju zamenjala enoumni odnos do sveta in vzvišen patetični izraz. $V$ Rimu protežirane novosti so, upoštevajoč skromno protestantsko dediščino $v$ glasbi, neverjetno hitro odmevale na Slovenskem. Neukemu ljudstvu je bila odmerjena kulisa glasbenih, ob pasionskih igrah in procesijah tudi gledaliških umetelnosti z zapeljivim zvočnim koloritom in scenskimi aluzijami. Pri tem je red kapucinov (po številu redovnikov je presegal vse druge redove na naših tleh) že leta 1591 začel skrbeti za sistematično prevzgojo preprostega prebivalstva. Značilne so njihove baročno povzdignjene, pogosto duhovite pridige s prispodobami iz vsakdanjega življenja in nepogrešljive, vselej z glasbo podkrepljene pasionske igre. ${ }^{3}$ Po mnenju Metoda Benedika so imeli tolikšen vpliv na najširši sloj ljudi, da so izoblikovali slovenski kulturni značaj v 17. in deloma 18 . stoletju. ${ }^{4}$

Glasbeno delo jezuitov, ki nosijo oznako mednarodnih ambasadorjev baročne umetnosti na visoki intelektualni ravni, je steklo na naših tleh prav tako zgodaj, ob začetku Hrenove dobe. Vojaška disciplina in red, po katerem namen posvečuje sredstva, sta zavladala tudi $v$ glasbenem seminarju in kolegijskem gledališču. Podatek, da sta bili dve tretjini profesorjev slovenskega rodu že ob ustanovitvi šole, ne preseneča, saj so domači škofi poskrbeli za talente in jih pred tem pošiljali na študij k jezuitom, največ v Rim in Gradec. Pomen jezuitskega delovanja pri nas še ni dokončno ovrednoten. $V$ glasbi sodimo, da se je z njihovim nastopom odprla slovenska tradicija poklicnega izobraževanja in gledališke umetnosti $z$ glasbo $v$ današnjem pomenu. Iz njihovih vrst je izšlo več generacij poklicnih glasbenikov in skladateljev. Omenimo le Janeza Krstnika Dolarja, poznejšega vodjo glasbene kapele $v$ cerkvi Am Hof na Dunaju in večino skladateljskega kroga ljubljanske Akademije filharmonikov. Na Primorskem se je nadpovprečno uveljavil v zgodnji baročni

2 Škof Janez Tavčar je bil od 1580-1597 namestnik nadvojvode v Gradcu. Tam so jezuiti odprli šolo I. 1583 (univerzo 1586); gl. France M. Dolinar, Pomen jezuitskega reda v verskem in kulturnem življenju na Slovenskem, v: Obdobje baroka v slovenskem jeziku, književnosti in kulturi. Obdobja 9. Ljubljana 1989, 379-384.

3 Gl. Niko Kuret, Duhovna drama, Literarni leksikon Slovenske akademije znanosti in umetnosti 13. zvezek, Ljubljana 1981; isti, Versko (duhovno) gledališče na Slovenskem v obdobju baroka, v: Obdobja, n.d., 395-415; Filip Kalan, Živo gledališko izročilo, Ljubljana 1980 (: tretje in peto poglavje).

4 Metod Benedik, Kapucini kot pomemben dejavnik $v$ oblikovanju duhovne podobe slovenskega naroda $v$ 17. in 18. stoletju, v: Obdobja, n.d., 385-392; Jože Rajhman, Vpliv zahodno-evropske mistike na slovensko literaturo 17. in 18. stoletja, v: Obdobja, n.d., 129. 
dobi toskanski mojster Gabriello Puliti (izšel je iz minoritskega reda), ob koncu 17. stoletja še Matej Melissa, organist v goriškem jezuitskem kolegiju in Antonio Tarsia iz Kopra. Še popolnejšo oceno njegovega dela bo verjetno odkrila nova najdba njegovih del, kakor smo pred kratkim slišali na valovih Radia Koper. ${ }^{5}$

Eno od osrednjih vprašanj, ki nas tu zanimajo, zadeva repertoar, oziroma sočasne glasbene novosti na Slovenskem, ki so utemeljile fenomen baroka in prispevale v skupno evropsko podobo tega obdobja. Reprodukcijo prve faze zrcali zdaj že znameniti Inventar muzikalij, popisan leta $1620 .{ }^{6} \mathrm{~V}$ njem najdemo domala istoveten izbor glasbenih novosti z generalnim basom in slogovnim sinkretizmom med renesančnim in baročnim, kot ga poznamo iz razvite glasbene dediščine drugod po Evropi. Zanj sodimo, da ni po naključju našel pot $v$ provincionalno deželo, temveč da sta mu botravala odličen razgled domače inteligence nad tedanjo novo glasbo in glasbena ozaveščenost, ki je nedvomno segla čez ideološke potrebe in zasebni manifestativni vzvod. Posebej navedimo le troje del: opero Euridice Giulia Caccinija ( $v$ dveh izvodih, Benetke 1600 in 1615) ter dve deli iz zgodnje oratorijske oblike s prav tako zvenečima skladateljskima imenoma; to sta Francesco Stivorio in Agostino Agazzari.

Oratorij in opera kot poglavitni obliki baročne glasbe sta ostali središčni še v poznejših fazah baroka na Slovenskem. Po smrti Tomaža Hrena leta 1630, sta bila strah pred politično ostrino katoliške obnove in skrajno negotova socialna razslojenost toliko odmaknjena, da se je mogel življenjski vsakdan otresti vročičnega stanja. Plemstvo si je sredi 17. stoletja precej opomoglo spričo ugodnega trgovskega pretoka čez domače ozemlje in vnovič dospelo do lastne glasbene reprezentance. Tokrat $v$ koraku s časom in po estetskih normah $v$ glasbi, ko je opera veljala največ. Leta 1652 so $v$ Ljubljani, v knežjem dvorcu izvedli malo opero La Garra, delo danes pozabljenega skladatelja Casparja Freysingerja (istega leta jo je krstil dunajski dvor ob rojstvu princese Margarete Terese). Sledili sta dve operi serii in 1660, v sekundarnem gradivu večkrat opevana izvedba komične opere pod imenom "commedia in musica". Z njo je deželni knez počastil obisk cesarja Leopolda I. $v$ kranjski prestolnici. ${ }^{7} \mathrm{O}$ slednji misli Stanko Škerlj, dober poznavalec slovenske gledališke preteklosti, da je šlo za gostovanje italijanske operne družine, kar naj bi Ljubljani zagotavljalo "omembe vredno mesto v zgodovini opere buffo". ${ }^{8}$ Po novih muzikoloških dognjanjih ne dvomimo več, da je bila res izvedena, $v$ tistem času še redka, glasbena komedija. Uprizorili so jo domači diletanti iz plemiških vrst na eno izmed priljubljenih zabavnih predlog, ki se ji je do danes ohranilo ime "commedia in musica". Zvrsti buffo opere glasba 17. stoletja še ni poznala, omembe vredna pa zagotovo ostaja naša uprizoritev iz drugega razloga: da se je v provinci - kot protiutež operi serii in pastoralnim favolam - sploh mogla zgoditi.

Naslednje znamenje okrepljenega plemstva izpričuje rojstvo Academiae Philharmonicorum Labacensis na prelomu v 18. stoletje. Ta ustanova je bila tudi znamenje spremenjenega časa in socialnega glasbenega zaledja. Z njo smo na Slovenskem dobili prvi glasbeni program, zaobjet $v$ natisnjenih Pravilih (Leges). Ločevala je zasebno muziciranje svojega članstva in glasbeni program za javnost. Vzdrževala je zbor in orkester, z njima sodelovala na pomembnejših prireditvah, regatah po Ljubljanici, slavnostnih sprejemih in podobnem. To je bila ena stran njenega, danes bi rekli glasbeno-političnega, delovanja. Druga stran je bila samoumevna potreba po ustvarjanju. Zgledovala se je v sestrski Akademiji operozov, obe skupaj pa v italijanskih akademijah. Te so zbirale smetano

5 Ustvarjalnost baročnih skladateljev na Primorskem je celovito predstavil J. Höfler v: Glasbena umetnost pozne renesanse in baroka na Slovenskem, Ljubljana 1978.

6 V celoti ga je navedel in dešifriral osnovne (znane) podatke J. Höfler v prilogi n.d..

7 Za podrobnejšo razlago teh predstav gl. K. Bedina, Vprašanje periodizacije glasbenega baroka na Slovenskem, v: Muzikološki zbornik XXVII, Ljubljana 1991, 56-57.

8 Stanko Škerlj, Italijansko gledališče v Ljubljani v preteklih stoletjih, Ljubljana 1973, 84. 
znanstvenih in umetniških umov. Priviligiran družbeni status so nadgrajevale $v$ tekmovalnem razmerju, kdo kaj zmore v svojem območju. Merjenje moči v glasbi je zadevalo predvsem ustvarjalno delo. Osrednja domena ljubljanske Akademije filharmonikov so bili oratorij, sodeč po sekundarnih virih. Izvedbe so očitno dosegle namen, ki so si ga filharmoniki predstavljali ob začetku: naj glasba duhu pot kaže. Slavo jim je na široko spel že Valvazor v Zgodovini Vojvodine Kranjske. Notno gradivo oratorijev se ni ohranilo. Nekateri ohranjeni, natisnjeni libreti govorijo za baročno obliko, ponekod z arijo da capo. Domnevamo, da so filharmoniki in skladatelji zunaj nje zložili znatno več del, kakor jih poznamo po imenih. Omenjena najdba skladb Antonia Tarsie med drugim potrjuje misel, da je $v$ baročni dobi zvenelo več doma ustvarjene glasbe. Poznamo sicer en sam, a zgovoren zgled, da so domači skladatelji sledili tudi modi drobnejših posvetil $v$ glasbi $z$ enigmatično zapletenim baročnim domislekom. Mislimo na Epiteta latino-germanica Janeza Bertolda Höfferja, ustanovitelja in prvega direktorja Akademije filharmonikov - in na tedanji odnos do glasbe oz. njeno navzočnost $v$ človeški intimi in skupnosti.

Repertoar, o katerem smo govorili, je $z$ delom Akademije filharmonikov nekoliko uravnotežil razmerje tujih in domačih avtorjev. Odprto ostaja vprašanje, kaj se je dogajalo v zasebnih kapelah, vendarle: leta 1732 beležimo prvo pri nas zloženo opero serio z naslovom II Tamerlano. Napisal in izvedel jo je kapelnik vicedoma grofa Turna Giuseppe Bonomo, za zdaj še neidentificirano skladateljsko ime. $V$ štiridesetih letih 18. stoletja je prvenstvo oratorija zamenjala opera v pravem valu jtalijanskih opernih družin. Vrstile so se priljubljene staggione, $s$ katerimi se poslej za daljše obdobje ni mogla meriti nobena druga zvrst. V kontinuiteto italijanskega glasbenega okusa je prodrla germanizacijska ideja pod oblastjo cesarice Marije Terezije, kljub temu, da je v glasbi doživljala močan odpor. Kazal se je $\vee$ kar pretiranem nerazpoloženju, ko se je nova oblast trudila spodriniti italijanska gostovanja z gostovanji nemških družin. Estetski odpor je usodno poglabljala centralistična volja politike, ki je provincam odrekla kulturno-umetniško samostojnost po duhovni in materialni plati. Franz Kafka in Robert Musil sta presodila habsburško monarhijo kot svojevrstno in razosebljeno totalitarno moro. Pri nas, če parafraziramo njuno stališče, je zamorila zgodnje, "pravočasno" reagiranje na nič manj veličastne spremembe v glasbi, ki so pripeljale klasicistično ero do neslutenih vrhov. Klasicizem je zaživel v slovenski glasbi šele ob koncu 18. stoletja z novo ustanovo, nemško Filharmonično družbo. Poslanstvo te družbe je bilo kajpada (zopet) reproduktivno.

\section{SUMMARY}

Celebrations marking the 300th anniversary of Tartini's birth, held in his birthplace, Piran/Pirano, have given rise to an examination of the musical background of his work in present-day Slovenia. That was the time of the baroque, which was followed by a gradual disintegration of baroque thinking in the second half of the 18th century and by a long overdue classicism in Slovene music. The paper is based on the present (general) approach to the baroque and is concerned with the awakening of all forms of musical works in Slovene provinces of that time which was due to a renewal of the strength of the Catholic Church. From 1630 on there was an increasing genuine musical awareness among the Slovene speaking population, which managed to overcome ideological barriers in favour of creating its own culture and art.

A survey of the repertoire with which baroque music established itself in three developmental phases is presented. The Jesuits introduced systematic musical education. The first opera performance, documented in the music-catalogue of the Ljubljana Cathedral before 1620 (G. Caccini and Euridice), was followed by several opera performances for an aristocratic audience (in 1660 also "comedia in musica"). The Academia philharmonicorum 
labacensis (founded in 1701) gave with its reproduction and production (especially of oratorios) the ultimate character to the period. Unfortunately, creative diversity was not fostered in the second half of the 18th century. The enlightened absolutism of the Habsburg monarchy denied any cultural artistic independence to its provinces, which severely interfered with the further development of Slovene music. 